\title{
Level of Managers' Professional Efficiency in Agricultural Multipurpose Cooperative Unions in Oromia Regional State, Ethiopia
}

\author{
Mr. Merga Futasa Begna \\ PhD Scholar at College of Business and Economics, Cooperative Department, Ambo University, Ambo, \\ Ethiopia \\ Professor S. Nakkiran (Dr.): \\ Lecturer at Ambo University; College of Business and Economics, Cooperative Department
}

\begin{abstract}
The main intent of this study is 'to examine the level of managers' professional efficiency in cooperative union to enhance Agricultural cooperative unions' business performances'. The study covers 228 respondents of sampled agricultural cooperative union. The study were employed both quantitative and qualitative research approach to answer the research question. The pertinent data related to the study was collected with the help of survey questionnaire, key informant interview and focus group discussion from the study participants. The pertinent data collected were analyzed with the help of descriptive statistics. Accordingly, the study result reveals that there were managers professional efficiency gap among managers of the sampled cooperative unions in the study. Therefore, the government, specifically the Cooperative promotion agency, concerned committees of the union must give due attention to the hiring of managers in respective of their technical and political professional efficiency and other human resource development like continuous trainings for cooperative managers on cooperative concepts, principles, values and business activities. Consequently, these actions will make sure the business competence of the cooperatives unions in the regional and national wise.
\end{abstract}

Keywords: Manager, Professional Efficiency, Cooperative, Business Performance

DOI: $10.7176 / \mathrm{JAAS} / 77-01$

Publication date: January $31^{\text {st }} 2022$

\section{Introduction}

Cooperatives have been criticized as being too focused on bulk production and too slow in responding to the market and competitors Johnson, M. (2004). With the changes in market conditions, a common concern is whether the cooperative is still an inefficient governance structure. Because of the production orientation and upstream focus, traditional cooperatives may be disadvantageous in competition with investment owned firms when downstream projects are more important. The major implication of cooperative structure in relation to professional efficiency is the need to ensure the channeling of basic technical services for the organization. It is only by pooling of resources at the optimal level that cooperatives can accumulate the specialized expertise and the capital needed to make available to their members of the advantages of large scale operation.

According to Lynch R (2009), agricultural cooperatives need to be managed by professional managers if they are to survive and grow in the wake of Ethiopian's economic policy and globalization. The challenge facing by the cooperatives today, particularly at Unions level is to develop professional experts and a good governance system that can support and sustain effective business to members in the cooperative enterprises.

To compound issues, members' confidence in the board of directors charged with monitoring the cooperative professional management performance and representing the interest of members has eroded (Borgstro,2013).

Although professional efficiency and governance at cooperative union level still needs more to be done in order to improve the business performance for the socio-economic wellbeing of every cooperative members in Oromia regional state. Therefore, this study will investigate effect of professional efficiency and cooperative governance on cooperatives' business performance and associated issues of the cooperatives and put forward considerable recommendations for the authorized cooperative bodies, policy makers and academicians.

\section{Material and Methodology}

Co-relational design was adopted in this study. Descriptive survey design was employed for the purpose of describing the state of existing managers professional efficiency in the sampled cooperative unions. The researcher systematically collected and analysed data to test hypotheses relating to managers professional efficiency in business performance of cooperatives. Co-relational design was enabled the researcher to map out the level of existing managers 'professionals efficiency of cooperatives. Purposive sampling technique was used to select the study area. There were 20 zones in Oromia Regional State. Out these 20 zones of the region four 
zones were selected purposively. Sample selection criteria of zones are nearness and accessibility of required data. These selected zones are West shewa, South west shewa, East Wollega and Horro Guduru Wollega. There are 97 agricultural multipurpose cooperative Unions in Oromia regional state, Ethiopia (Oromia cooperative Agency Office, 2018). Out of these 97 cooperative unions 9 are selected purposively based up on nearness to the researcher, professional employees and accessibility of the required data for achieving the study objectives. The 228 total sample size of the individual respondents are calculated from the total population 529 using Yamane (1967) formula. Both quantitative and qualitative methods were employed. The primary data were obtained by key informant interviews guided by checklist from board members, managers and through both open ended and closed ended questionnaire from relevant respondents to achieve the objective of the study. Blaikie (2003) observes that it has become common practice to assume that Likert-type categories constitute interval-level measurement where five point Likert scales will be used. Copies of questionnaire schedule with the cover letter distributed for 228 respondents for the collection of data. The questionnaires were translated in local language to make it easier for the respondents to avoid ambiguity of language.

\section{Data Analysis}

Pertinent data were collected and properly organized and prepared for codification. Following this, the coded data were fed to SPSS software program. To meet the objective of the research the collected data were analysed using descriptive statistics mean value, minimum, maximum and standard deviation.

\section{RESULTS AND DISCUSSION}

\section{Level of Managers' Professional Efficiency in the Selected Cooperative Unions.}

Table 4.2 below, shows the response of respondents on whether the Managers in the cooperative offer technical advice for the board members. It shows that $115(51 \%)$ and $49(21 \%)$ respondents strongly agreed and agreed that cooperatives mangers can offer technical advice. Also, the result of the study shows that 15(7\%) and 19(8\%) strongly disagreed and disagreed that cooperative managers in the study area could give technical advice to the board members, while $30(13 \%)$ of the respondents. This result implies that majority of the respondents agreed that there is efficient technical advice for the board members and this enhances the performance of business activities in the selected cooperative unions in the Oromia region,Ethiopia.

The below table 4.2 shows that, $87(39 \%)$ of the respondents agreed that there is managers efficiency in generating business ideas to solve problems with business environment changes, 51(22\%) of them strongly agreed with this position while 28(12\%) and 56(25\% disagreed and undecided. This result implies that there is a cooperative business knowledge gap among cooperative union managers in the study area.

Table 4.2: Level of Managers Professional Efficiency

\begin{tabular}{|c|c|c|c|c|c|c|c|c|c|c|c|}
\hline \multirow[b]{2}{*}{ 이 $^{\prime}$} & & \multicolumn{2}{|l|}{1} & \multicolumn{2}{|l|}{2} & \multicolumn{2}{|l|}{3} & \multicolumn{2}{|l|}{4} & \multicolumn{2}{|l|}{5} \\
\hline & & $\mathrm{Fr}$ & $\%$ & $\mathrm{Fr}$ & $\%$ & $\mathrm{Fr}$ & $\%$ & $\mathrm{Fr}$ & $\%$ & $\mathrm{Fr}$ & $\%$ \\
\hline 1 & $\begin{array}{l}\text { Managers offer technical advice for the board } \\
\text { members. }\end{array}$ & 15 & 7 & 19 & 8 & 30 & 13 & 115 & 51 & 49 & 21 \\
\hline 2 & $\begin{array}{l}\text { Managers have been tried to adopt new technology } \\
\text { and equipment (like industry innovations, improved } \\
\text { machineries, computer systems and research results). }\end{array}$ & 22 & 10 & 77 & 34 & 35 & 15 & 44 & 19 & 50 & 22 \\
\hline 3 & $\begin{array}{l}\text { Managers have been developed new product/ services } \\
\text { (that means product additions, replacements and } \\
\text { product in formations'). }\end{array}$ & 6 & 3 & 86 & 37 & 19 & 8 & 69 & 31 & 48 & 21 \\
\hline 4 & $\begin{array}{l}\text { Policy set, strategic proposed by board of directors } \\
\text { have been implemented by the managers in your } \\
\text { cooperative union efficiently. }\end{array}$ & 6 & 3 & 95 & 41 & 26 & 11 & 61 & 27 & 40 & 18 \\
\hline 5 & $\begin{array}{l}\text { Managers are efficient in generating ideas of policy } \\
\text { changes to solve problems with business environment } \\
\text { changes. }\end{array}$ & 6 & 3 & 28 & 12 & 56 & 25 & 87 & 39 & 51 & 22 \\
\hline 6 & $\begin{array}{l}\text { Managers are efficient in maintaining a competent } \\
\text { staffs (that means selects, recruits, trains, hires and } \\
\text { supervises employees) direct bearing on how well the } \\
\text { cooperative business performs. }\end{array}$ & 9 & 4 & 38 & 17 & 45 & 20 & 93 & 41 & 43 & 18 \\
\hline 7 & $\begin{array}{l}\text { Managers are efficient in informing members via } \\
\text { website or social media about the business a } \\
\text { performances of their union. }\end{array}$ & 17 & 8 & 52 & 23 & 46 & 20 & 62 & 27 & 51 & 22 \\
\hline
\end{tabular}




\begin{tabular}{|c|c|c|c|c|c|c|c|c|c|c|c|}
\hline \multirow[b]{2}{*}{ 이 } & & \multicolumn{2}{|l|}{1} & \multicolumn{2}{|l|}{2} & \multicolumn{2}{|l|}{3} & \multicolumn{2}{|l|}{4} & \multicolumn{2}{|l|}{5} \\
\hline & & $\mathrm{Fr}$ & $\%$ & $\mathrm{Fr}$ & $\%$ & $\mathrm{Fr}$ & $\%$ & $\mathrm{Fr}$ & $\%$ & $\mathrm{Fr}$ & $\%$ \\
\hline 8 & $\begin{array}{l}\text { Managers are timely preparing inclusive business plan } \\
\text { (that means in content, strategic, achievable, } \\
\text { measurable, time bound). }\end{array}$ & 5 & 2 & 30 & 13 & 55 & 24 & 80 & 35 & 59 & 26 \\
\hline 9 & $\begin{array}{l}\text { Managers are efficient in predicting cooperative } \\
\text { businesses. }\end{array}$ & 11 & 5 & 35 & 15 & 55 & 24 & 86 & 38 & 41 & 18 \\
\hline 10 & $\begin{array}{l}\text { Managers have been able to monitor business risk in } \\
\text { order to strengthen business performance of your } \\
\text { cooperative union. }\end{array}$ & 12 & 5 & 51 & 23 & 46 & 22 & 69 & 30 & 47 & 20 \\
\hline 11 & $\begin{array}{l}\text { Managers are efficient in teaming skill of staffs in the } \\
\text { cooperative union. }\end{array}$ & 9 & 4 & 44 & 20 & 78 & 34 & 52 & 23 & 45 & 19 \\
\hline
\end{tabular}

Source: Survey data, 2021

Note: 1, strongly disagree, 2, disagree 3. Undecided 4. Agree 5. Strongly agree, Fr, frequency, $\%$, percentage

Adopting or innovating new technology and equipments like industry innovations, improved machineries, computer systems and research results are very essential for the business development of the cooperative union. The research result above in table 4.5 indicates that $77(34 \%$ ) of the respondents disagreed managers are not efficient in adopting new technologies and results, 50(22\%) of them strongly agreed that managers are adopting research results and adopted new technologies while $44(19 \%)$ of the respondents agreed that managers are not involved in adopting important new technologies and research results, 22(10\%) strongly disagreed with this statement, and 35((15\%) were undecided. From the study result one can conclude that managers are not efficient in adopting research results and new technologies which increases the business performance of the selected cooperative unions in the oromia regional state (Table 4.2).

As shown in above table 4.2 , majority of the respondents about $86(37 \%)$ and $6(3 \%$ disagreed and strongly disagreed about the efficiency of managers in developing new product/ services, value additions, replacements and product in formations 'in the business undertakings of their cooperative union and also about 19(8\%) of respondents undecided. Only about $69(31 \%)$ and $48(21$ of the respondents agreed and strongly agreed to the managers' efficiency in developing new products and service, value additions, replacements and product in formations in their cooperatives business activities. From this result one can deduce that, there is a problem among managers of the cooperatives in developing new products and service issues of cooperative businesses and this problem in turn affect the performance of the cooperative union business activities.

Seeing that the above table 4.2 , greater part of the respondents $95(41 \%)$ and $6(3 \%)$ disagreed and strongly disagreed about managers' efficiency in implementation of business strategic proposed by board of directors and also about 26(11\%) of respondents undecided about efficiency of the selected cooperative union in the businesses of the cooperative. Only about $61(27 \%)$ and $40(18) \%$ of respondents agreed and strongly agreed to implementation of business strategic proposed by the board of directors in their cooperatives. From this result one can figure out that, there is a difficulty along with selected cooperative union managers in the study area and this difficulty in turn impinge on the performance of the cooperative business activities.

As evident from Table 4.5 above shows that 93(41\%) and 43(18\%) of the respondents agreed and strongly agreed that there is adequate selection, recruitment hiring, training and supervision of competent staffs in the cooperative unions in the study area where as, 38(17\%) and $9(4 \%)$ of the respondents disagreed and strongly disagreed with the efficiency of managers in the oromia regional state. This result indicates that selecting, recruiting, hiring and training adequate man power in the cooperative union enables the union to increase its business performance in the market environment under the umbrella of Ethiopian cooperative legislation.

To ensure the transparency and increases the participation of members in the every business activities of cooperatives, managers efficiency in informing members and other authorized bodies about the business performance is so vital. Accordingly, the above table 4.5 confirms, about $62(27 \%)$ and $51(22 \%)$ of respondents opined as agreed and strongly agreed about their efficiency of informing via website of the cooperative about the business performance of the union and about $46(20 \%)$ of respondent's undecided about the issue. Contrary to these, about $52(23 \%)$ and $17(8 \%)$ of respondents responded as disagreed and strongly disagreed with managers efficiency in informing about the business activities in their cooperative union. From this result one can concludes that, majority of the respondents revealed that there is a understanding among managers of the cooperatives in informing about the business activities of their cooperative union which in turn increases the business performance(see table 4.2 above).

Managers are responsible to timely prepare inclusive business plan which consists full content, strategic, achievable, measurable and time framed to increase the level of business performance of the cooperatives. 
Accordingly, about $80(35 \%)$ and $59(26 \%)$ of the respondents agreed and strongly agreed with the managers efficiency in timely preparation of inclusive business plan. Moreover, about 55(24\%) of respondents opined as undecided about the managers efficiency in inclusive business plan preparation their cooperative union. Only the rest $30(13 \%)$ and $5(2 \%)$ of respondents disagreed and strongly disagreed with the efficiency of managers in inclusive business plan preparation. This shows significant number of respondents agreed to the timely preparation of inclusive business plan of the cooperative businesses at optimum level and take the cooperative business forward (see table 4.2 above).

Table 4.2 above, revealed that $86(38 \%)$ of respondents agreed managers are efficient in predicting cooperative business activities at Oromia regional state, $41(18 \%)$ of respondents agreed, $35(15 \%)$ of respondents disagreed and $11(5 \%)$ of respondents strongly disagreed. Overall, $56 \%$ of respondents either strongly agreed or agreed that there is managers' efficiency in predicting cooperative business activities in the study area.

Regarding the respondents Knowledge of mangers efficiency in monitoring business related risk, about $69(30 \%)$ and $47(20 \%)$ of respondents agreed and strongly agreed respectively and about $46(22 \%)$ of respondents opined as undecided about their knowledge of mangers efficiency in monitoring business related risk, while the rest $12(5 \%)$ and $51(23 \%)$ of respondents replied as strongly disagreed and disagreed with their knowledge of mangers efficiency in monitoring business related risk. This result indicates that, majority of the managers are efficient in mangers monitoring business related risk in their cooperative union business activities and this fact positively affects the business performance of the cooperatives(see table 4.2 above).

Accordingly, managers practices in teaming skill of staffs output was seen, about $78(34 \%)$ and $44(20 \%)$ of respondents were strongly disagreed and disagreed about their performance in managers teaming skill of staffs on business activities of the selected cooperative unions and also about $9(4 \%)$ of respondents were opined as undecided about the managers practices in teaming skill, while the rest 52(23\%) and 45(19\%) of respondents revealed as agreed and strongly agreed with the idea respectively. This shows that there is great gap with managers of teaming skill of staffs in the cooperative unions in the study area and this directly affects the business benefits of the cooperative unions (see table 4.2 above).

Table 4.-3: Level of Managers' Efficiency in motivational, Leading, Conflict resolution, Cooperative knowledge and communication Skills

\begin{tabular}{|c|c|c|c|c|c|c|c|c|c|c|}
\hline & $\mathrm{Fr}$ & $\%$ & $\mathrm{Fr}$ & $\%$ & $\mathrm{Fr}$ & $\%$ & $\mathrm{Fr}$ & $\%$ & $\mathrm{Fr}$ & $\%$ \\
\hline $\begin{array}{l}\text { Managers are efficient in motivating high performer } \\
\text { staffs in the cooperative union. }\end{array}$ & 20 & 9 & 46 & 20 & 25 & 11 & 120 & 53 & 17 & 7 \\
\hline $\begin{array}{l}\text { Managers are efficient in leading the cooperative } \\
\text { business and staffs in the cooperative union. }\end{array}$ & 12 & 5 & 72 & 31 & 53 & 24 & 46 & 20 & 46 & 20 \\
\hline $\begin{array}{l}\text { Managers are experienced in conflict resolution skill in } \\
\text { your cooperative union. }\end{array}$ & 12 & 5 & 51 & 23 & 75 & 33 & 38 & 17 & 52 & 22 \\
\hline $\begin{array}{l}\text { Managers are well oriented in cooperative management } \\
\text { knowledge. }\end{array}$ & 30 & 13 & 80 & 35 & 40 & 18 & 62 & 27 & 16 & 7 \\
\hline Managers have been experienced in decision making. & 9 & 4 & 34 & 15 & 39 & 17 & 89 & 37 & 57 & 25 \\
\hline $\begin{array}{l}\text { Managers have good communication with members, } \\
\text { boards of directors and managers }\end{array}$ & 0 & 0 & 25 & 11 & 51 & 23 & 105 & 47 & 44 & 17 \\
\hline $\begin{array}{l}\text { Managers teach to the customers about the benefit and } \\
\text { work of the cooperative. }\end{array}$ & 38 & 17 & 0 & 0 & 42 & 19 & 105 & 46 & 40 & 18 \\
\hline
\end{tabular}

Source: Survey Data (2021)

Table 4.3 above, revealed that $120(53 \%)$ and $17(7 \%)$ of respondents agreed and strongly agreed that there is efficiency managers in motivating high performers in selected cooperative union ,46(20\%) and 20(9\%) of respondents disagreed and strongly disagreed. While $25(11 \%)$ of opined that undecided. Overall, $137(60 \%)$ of the respondents either strongly agreed or agreed that there is there is efficiency managers in motivating high performers in selected cooperative union in the study area. This finding implies that motivating the high performers in cooperative union by managers is very essential to create efficient business performance of the cooperatives. These findings concurs with Wambua (2011) conclusion that employees motivation affected the financial performance of the SACCO.

Majority of the respondents $72(31 \%)$ disagreed that managers are efficient in leadership of the business of the selected cooperative union in the study area. 53(24\%)of the respondents undecided(indifferent) with the statements, 46(20\%) agreed,46(20\%) strongly agreed while 12(5\%) strongly disagreed. The result implies that there is leadership skill gap beside managers in leading staffs and cooperative union business activities in the study area and these professional inefficiency cooperatives managers negatively affects the business performance of the cooperatives(Table 4.3 above).

Wisely identifying and resolving conflicts leads to the low economic cost and social costs. Early conflict 
resolution is a must for the cooperative members, board of directors and for paid staffs of the cooperatives. For this reason managers are obligated to ensure the principle conflict resolution skill as a code of best practice in their cooperatives. However, according to majority $75(55 \%)$ of respondents disagreed that managers are experienced in conflict resolution and 51(23\%) of the respondents strongly disagreed, 52(22\%) and 38(17\%) of the respondents strongly agreed and agreed. The remaining, 12(5\%) of the respondents were opined undecided (see table 4.3 above). The result shows that hiring (appointing) inexperienced managers for cooperatives expands conflicts which results poor business performance in cooperatives.

The survey result indicated in above table 4.3 , the majority $80(35 \%)$ of respondents' opinion fall under the category of disagreed with the statement of managers are well oriented in cooperative knowledge and $62(27 \%)$ respondents agreed that managers are well cooperative knowledge oriented in the study area. $40(18 \%)$ of the respondents opined that undecided and $30(13 \%)$ of the respondents strongly disagreed with the statement. This shows that appointed (hired) managers in the cooperative union have no cooperative knowledge and concepts but they are enriched with political orientation. However, having managers oriented in both cooperative knowledge and political concept is one that must be known and exercised by the cooperatives.

As evident from Table 4.3 above, efficiency of managers in decision making skill, about $89(37 \%)$ and $57(25 \%)$ of respondents agreed and strongly agreed respectively and about $39(17 \%)$ of respondents opined as undecided about the efficiency of managers in decision making skill, while the rest $34(15 \%)$ and $9(4 \%)$ of respondents replied as disagree and strongly disagree with their knowledge of efficiency of managers in decision making skill in business activities. This result indicates that, majority of the respondents agreed or strongly agreed that managers were efficient decision making and has decision making skill in their cooperatives business activities and this fact positively influences the business performance of the cooperatives.

As it is stated in the legislation of cooperative there must be good industrial relationship among the cooperatives stake holders. Accordingly, on this particular point, about 105(47\%) and 51(23\%) respondents were agreed and strongly agreed about employees good communication with managers, members and board of directors. About $44(177) \%$ of respondents were undecided about the issue. Whereas, about $25(11 \%)$ of respondents were opined as disagree with employees ability to communicate properly. This result shows that managers of the cooperative union have good communication skill with members, board of directors and managers during running the business activities of the cooperative union and this skill in turn absolutely positively affects the individual member in particular and the business performance of the cooperatives in general(Table 4.3).

To ensure economic benefits of cooperative unions for members in particular and for the potential members in general employees expected to teach about the benefit of cooperatives during service delivery at the market spout as members gain dual benefits from their cooperatives. Accordingly, employees practices in teaching customers about the dual benefits of cooperatives was seen; about $105(46 \%)$ and $42(19 \%)$ of respondents were agreed and strongly agreed with the statement. And also about 40(18\%) of respondents were opined as undecided, while the rest $38(17 \%)$ of respondents opined as strongly agree with the idea. This show, managers were efficient in advertising the cooperative necessity and this directly affects the business performance of cooperatives (Table 4.3).

\section{Descriptive Statistics}

Table 4.4 : Analysis of Descriptive Statistics of Mangers professional skills

\begin{tabular}{|c|c|c|c|}
\hline Indicators of Managers Professional Skills & $\mathrm{N}$ & Mean & Std. Deviation \\
\hline Technical Skill & 228 & 3.77 & 1.058 \\
\hline Staff maintenance skill & 228 & 3.55 & 1.016 \\
\hline Teaming Skill & 228 & 3.32 & 1.150 \\
\hline Motivational Skill & 228 & 3.36 & 2.903 \\
\hline Leading skill & 228 & 3.18 & 1.228 \\
\hline Conflict Resolution Skill & 228 & 3.27 & 1.181 \\
\hline Communication Skill & 228 & 3.76 & 1.923 \\
\hline Decision making Skill & 228 & 3.61 & 1.154 \\
\hline Valid N (list wise) & 228 & & \\
\hline
\end{tabular}

Source: Calculated from Survey data(2021)

Table 4.4 above describes that, the respondents perceived that the managers' professionals' efficiency is very essential component to make competent and better business performance of cooperatives. The high mean score indicates that managers of the cooperatives were professionally efficient in running the business of the cooperative union in the study area. Accordingly, managers' in technical skill, staff maintenance skill, teaming skill, leading skill, decision making skill, conflict resolution skill and motivational skill professional efficiency in their own cooperative union have the mean values of mean=3.77 ,3.55, 3.32, 3.18, 3.61, 3.27 and 3.36 
respectively. From these results one can understand that, the level of managers professionals efficiency is less sufficient to strategically run a business the specified environment in line with their expected professionalism in the sampled cooperative union in the study area. Mean of data illustrate a summary of data and standard deviation displays how well the means represent the data (Field, 2009). All the mean scores and the standard deviation range between 3.18 and 3.77 and 1.270 and 2.903 respectively. This implies that data points are close to means and therefore, calculated means highly represent the observed data.

\section{Conclusion}

After the analysis of the level of professional efficiency of managers of selected agricultural multipurpose cooperatives unions in the study area, this study concluded that the existing level of managers' professional efficiency is less sufficient to strategically run a business of the in line with their expected professionalism in the sampled cooperative union in the study area. The reason behind was the existing managers in the sampled cooperatives in the study area did not provide the vital (anticipated) professionals efficiency for their cooperatives as the cooperatives business will become effective and remain to be the major business which stabilize the market of the study area to secure better income for members in particular and for the whole community in the region in general as is believed to be.

\section{Recommendation}

Lack of professional managers in selected cooperatives poses a big challenge to the cooperatives in maintaining the business performance of the cooperatives. The analysis result shows that respondents have witnessed that cooperative unions were not managed by educated professionals. To improve the cooperative managers professionalism, hiring professional managers is the crucial task of professionals ought to be geared up by the members of cooperative board committees and cooperative promotion agencies, based on their technical efficiency and giving continuous training for the managers and more consideration should be put on the managers professional efficiency in the study area.

\section{Acknowledgement}

The author acknowledges Professor S.Nakkiran (PhD), for his dedicated support, supervision, and counselor throughout this work. I also want to thank the study respondents for their open, honest and truthful answers and for the considerable time and insight they dedicated despite their already full schedules.

I am deeply indebted to Ambo University for research funding for successful completion of the study. I also need to acknowledge my parents specially my wife s/r. Desistu Gadisa Wakjira for her relentless teachings on the value of words of GOD, motivation, hard work and support.

\section{There's no conflicts of interests regarding this article.}

\section{References}

Blaikie N, (2003). Analyzing quantitative data, London, Sage publications.

Borgstro, M.(2013). Effective cooperative governance: A practitioner's perspective. Cooperative Organization and Management. $\mathrm{p} 49-50$.

Johnson, M. (2004) 'Gallup study reveals workplace disengagement in Thailand', The Gallup Management Journal.

Lynch R (2009). Strategic Management, London, Pearson Education Publisher. 